\title{
SEASONAL VARIATION OF PHYTOPLANKTON IN TUYEN LAM RESERVOIR IN DA LAT, VIETNAM
}

\author{
Tran Thi Tinh ${ }^{1}$, Doan Nhu Hai ${ }^{2}$, Le Ba Dung ${ }^{1}$ \\ ${ }^{1}$ Da Lat University, Vietnam, *tinhtt_env@yahoo.com \\ ${ }^{2}$ Nha Trang Institute of Oceanography, VAST
}

\begin{abstract}
Seasonal variation and phytoplankton dynamics in Tuyen Lam reservoir in Da Lat city, Viet Nam were studied in the rainy and dry seasons (during January through December, 2014). Samples were taken monthly from 3 stations of Tuyen Lam reservoir. The aim of this study was to analyze the structure of the phytoplankton community on seasonal scales and to identify the environmental factors, such as temperature, conductivity, $\mathrm{pH}$, dissolved oxygen, light intensity, transparency, ammonium, nitrate and phosphate controlling the phytoplankton density and composition of phytoplankton communities. The results showed that phytoplankton comprised 43 taxa, mainly Chlorophyta (58\%), Bacillariophyta (14\%), Cyanobacteria (14\%), Dinophyta (7\%), Chrysophyta $(5 \%)$ and Euglenophyta $(2 \%)$. There was significant difference in phytoplankton abundance but not species richness between two seasons. Multiple regression analysis between chlorophyll $a$ contents, phytoplankton density with environmental independent variables indicated that ammonium, nitrate concentrations and water temperature were significantly impact to the abundance of phytoplankton, while almost no independent variables were found to correlate to chlorophyll $a$. CCA analysis phytoplankton and abiotic parameters revealed several species groups with their favorable environmental conditions.
\end{abstract}

Keywords: Environmental factors, phytoplankton composition, reservoir, seasonal variation.

\section{INTRODUCTION}

The knowledge on how species interact within ecosystems is necessary to understand how natural and anthropogenic pressures will affect ecosystem structure and functioning [26]. Phytoplankton is a major producer in any aquatic ecosystem. The species composition and phytoplankton community dynamics are influenced by several factors, including available nutrients (nitrogen, phosphorus), physical variables (temperature, conductivity, $\mathrm{pH}$, dissolved oxygen, light intensity, transparency) and biological interactions (competition and grazing) [3, 15, 17, 23]. With a great variation of adaptive strategies, groups of phytoplankton are successful in many freshwater bodies [25]. The study of dynamics of phytoplankton is well-developed in many parts of the world $[4,10,13,16,14]$. These studies were crucial to an understanding of the ecosystem dynamics in lakes and reservoirs. In Viet Nam, there were several publications in phytoplankton research, but most have been dealing with taxonomy and species composition
[20, 21, 27], and only few studies were about impacts of environment on phytoplankton. There was completely lack studies on composition of phytoplankton as well as factors that effect structure of phytoplankton community in reservoirs in Da Lat city, Lam Vien highland. These reservoirs are presently considered to be polluted as they receive run off and untreated wastewater from agriculture (Dankia, Xuan Huong, Da Thien, Tuyen Lam reservoirs) and domestic waste (Xuan Huong reservoir) [29]. Tuyen Lam reservoir located 4 kilometers northwest of the Da Lat city, is a medium reservoir dam, constructed since 1983 and being used for drinking and irrigating water. The water level is high during the rainy season and low when the water is used without being refilled during the dry season due to the reservoir for irrigating water. The reservoir suffers from nutrient loading associated with sediment influx which resulted from massive erosion linked to land degradation. However, there was limited information about phytoplankton of the reservoir. Understanding 
relationship within the microbial food web of the reservoir, especially impacts of environmental factors on composition of phytoplankton is scientifically important and would contribute valuable data for a scientific based water management in Tuyen Lam reservoir. This present study applied analysis on data sets of abiotic environmental conditions and phytoplankton community structure to understand and/or identify the processes and factors that affect phytoplankton during a oneyear period.

\section{MATERIALS AND METHODS}

\section{Study area}

Tuyen Lam reservoir is located at latitude of $11^{\circ} 53 \mathrm{~N}$ and longitude of $108^{\circ} 25 \mathrm{E}$ in Da Lat city, Lam Dong province, Vietnam (fig. 1). This region characterized by two climatic seasons, rainy season (April-October), and dry season (November-March). The total area of Tuyen Lam reservoir is about 303.49 hectares. The reservoir has a mean depth of $9.88 \pm 1.28 \mathrm{~m}$. The reservoir was reconstructed in 1983 for irrigating and drinking water.

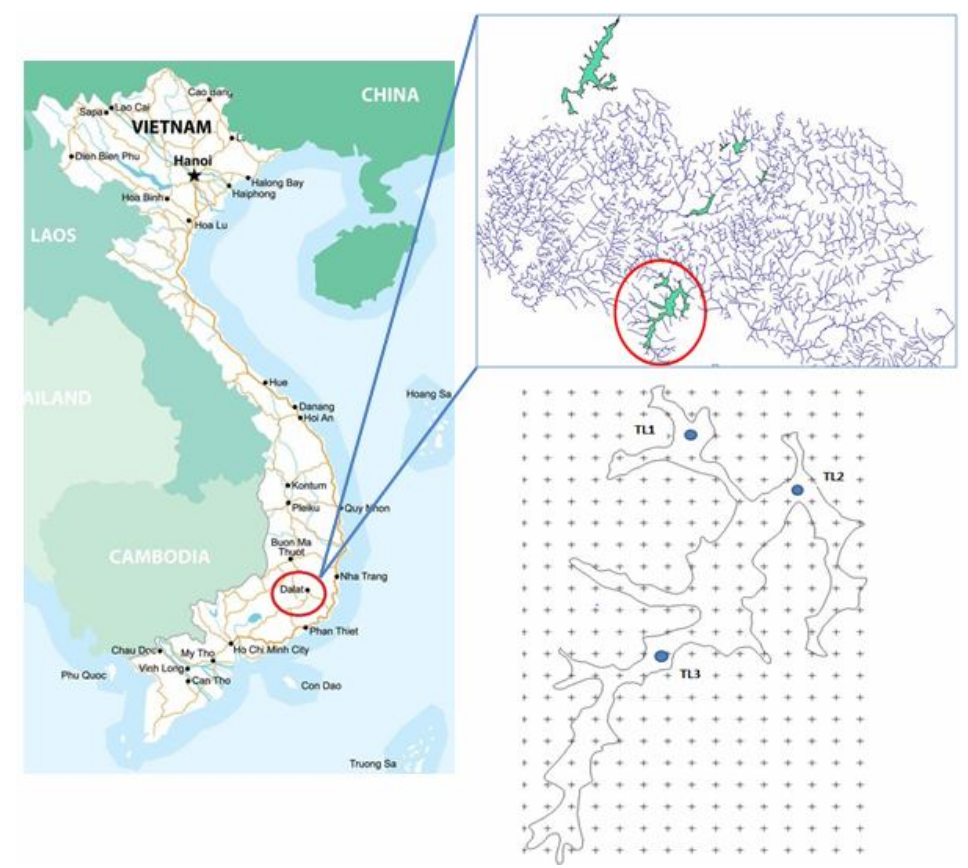

Figure 1. Study area and sampling stations in Tuyen Lam reservoir.

\section{Sample collection and analysis}

Sampling was carried out monthly at three stations (fig. 1) from January to December 2014. Although data was collected monthly, the results were represented seasonally as the rainy (April-October) and the dry season (NovemberMarch). Values of biotic and abiotic variables were presented as the mean of three stations $(n=3)$. At each station, samples were collected from two layers, surface layer (from 0 to $50 \mathrm{~cm}$ ) and at bottom of the euphotic zone. The euphotic zone was estimated by using a factor of 2.0 to 2.7 times the Secchi disk depth (Cole,
1994) [5]. Water temperature, conductivity, and $\mathrm{pH}$ were measured by using a 330i/SET multiprobe (USA). Dissolved oxygen was measured with portable digital potentiometer. Water transparency was estimated by a Secchi disk. Light intensity was measured by light meter (Extech Instruments, USA). Ammonianitrogen $\left(\mathrm{NH}^{+}{ }_{4}-\mathrm{N}\right)$, nitrate-nitrogen $\left(\mathrm{NO}^{-}{ }_{3}-\mathrm{N}\right)$ and phosphate $\left(\mathrm{PO}_{4}{ }^{3-}\right)$ concentrations were measured followed standard methods [2]. Phytoplankton quantitative samples were collected using Niskin bottle at the two layers. Qualitative phytoplankton samples were 
collected using a conical net with $25 \mu \mathrm{m}$ mesh size. Phytoplankton samples were fixed with a $1 \%$ acid Lugol solution [31]. Analysis of chlorophyll $a$ was followed US. EPA $(10200 \mathrm{H})$ [2]. The phytoplankton were identified from live and Lugol-fixed samples under an Olympus microscope BX 41. Identification was done following Komárek et al. (2000) [11], Komárek et al. (2005) [12] and John \& Robert (2003) [9]. Phytoplankton were quantified using Sedgewick-Rafter chamber and by counting individuals of the most frequent taxon (including filamentous cyanobacteria as Anabaena spiroides và Oscillatoria sp.) under a microscope at $400 \times$ according to Hotzel \& Croome (1999) [7].

\section{Data analysis}

Relationship between species composition of phytoplankton and environmental variables were analysed using canonical correspondence analysis (CCA). CCA is a direct ordination technique that selects the combination of environmental variables which maximize the dispersion of the scores of phytoplankton species. In this analysis, the matrix with biotic data was constructed with abundant species. The abbreviated names of species were given in the taxonomic table (table 2). Species accounting for more than $1 \%$ of the variance in each variable were considered to be selected by this variable. CCA plots represent overlap of species in relation to a given combination of environmental variables in each studied month. All the analyses were accomplished with the CANOCO 4.5 Program for Window. The regression analysis was calculated by using abundance phytoplankton, chlorophyll $a$ contents as dependent variable and abiotic factors as independent variables with the help of Statgraphic plus 5.0 for Windows. The mean, standard deviation (SD) were calculated by Microsoft excel and $\mathrm{P}$ values were calculated for ANOVA among seasons, depths and stations. Means and standard deviation of all measurements (with three repetitions) and three stations were recorded for each parameter.

\section{RESULTS AND DISCUSSION}

\section{Physical and chemical characteristics}

Physical, chemical and biological variables of the water of Tuyen Lam reservoir at all sampling sites during the study period are presented in table 1. The average of these variables (at $0-50 \mathrm{~cm}$ layer) was described in fig. 2.

Water temperature ranged from 16.27 (July) to $22.67^{\circ} \mathrm{C}$ (April) (fig. 2A), with an average of $19.11 \pm 1.95^{\circ} \mathrm{C}$ in the rainy and $18.41 \pm 1.30^{\circ} \mathrm{C}$ in the dry seasons. There was no difference in temperature among stations in both of seasons at $0.5 \mathrm{~m}$ (ANOVA, $\mathrm{p}=0.069)$ as well as at both depths (ANOVA, p=2.94) (table 1). However, $\mathrm{pH}$ was higher in the dry than in the rainy seasons at $0.5 \mathrm{~m}$ (ANOVA, $\mathrm{p}=0.049$ ), but similar all year round at the bottom of photic layer (fig. 2B and table 1). $\mathrm{pH}$ ranged from neutral (6.96) to slightly alkaline (7.97) values. Dissolved oxygen ranged from 5.16 to 7.73 $\mathrm{mg} / \mathrm{l}$. There was a slight increase in dissolved oxygen in the rainy season. DO was higher in the rainy than in the dry season at both layers (ANOVA, p=0.013, and 0.047) but not different from surface and the bottom of photic zone (table 1). During rainy season, water level of the reservoir was rising higher than in the dry season (fig. 2D, table 1).

Total daily irradiation varied between 776 lux in December and 50966 lux in April. The water transparency (Secchi depth) was relatively high all through the seasons, ranging between $0.8 \mathrm{~m}$ and $3.5 \mathrm{~m}$. Therefore, the euphotic zone ranged from $1.6 \mathrm{~m}$ to $7.0 \mathrm{~m}$. Light intensity was higher in the rainy than in the dry seasons (ANOVA, $\mathrm{p}=0.00$, fig. 2I and table 1). Water transparency in the rainy was higher in the dry seasons. This may be explained by high irradiation recorded during early rainy season (April-May). In Tuyen Lam reservoir, high light intensity during April-May when water temperature high may favor phytoplankton growth. That would explain phytoplankton peak in April (fig. 2J).

Electrical conductivity was generally high and varied between 58.67 and $64.67 \mu \mathrm{S} / \mathrm{cm}$. The EC values were not different among 3 stations in both seasons (ANOVA, $\mathrm{p}=0.236$, fig. $2 \mathrm{~F}$, table 1).

Relatively low nutrient concentrations were 
recorded during 2014. Ammonia concentration varied from 0.07 to $0.64 \mathrm{mg} / \mathrm{l}$, higher at surface water in the rainy than in the dry season (ANOVA, $p=0.007$ ). Nitrate concentrations were higher in the dry than in the rainy season at both layers (ANOVA, $\mathrm{p}=0.028$ ). Average phosphate concentration was $0.46 \pm 0.45 \mathrm{mg} / \mathrm{l}$ in the rainy and higher $(0.55 \pm 0.26 \mathrm{mg} / \mathrm{l})$ in the dry seasons. Phosphate values were much varied in the rainy than in the dry season (table 1). Both nitrate and phosphate concentration were completely depleted in August (fig. 2G). During this month, chlorophyll $a$ content was highest, thus, phytoplankton may be involved in using all nutrients for that massive biomass.

All physical and chemical parameters were not different between surface and bottom of the photic zone layers may imply that the photic zone of Tuyen Lam reservoir was quite well mixed through out the year.

Table 1. Physical, chemical and biological parameters between the rainy and the dry seasons in Tuyen Lam reservoir

\begin{tabular}{|c|c|c|c|c|c|c|c|c|}
\hline \multirow{2}{*}{$\begin{array}{c}\text { Physical, chemical and } \\
\text { biological parameters }\end{array}$} & \multicolumn{3}{|c|}{$\begin{array}{l}\text { Rainy season } \\
\text { (Apr. - Oct.) }\end{array}$} & \multicolumn{3}{|c|}{$\begin{array}{l}\text { Dry season } \\
\text { (Nov.- Mar.) }\end{array}$} & \multicolumn{2}{|c|}{$\begin{array}{c}\text { Significant } \\
\text { difference }(p)\end{array}$} \\
\hline & Min & $\operatorname{Max}$ & Mean \pm SD & Min & Max & Mean \pm SD & Seasons & Layers \\
\hline Water depth $(\mathrm{m})$ & 8 & 13 & $9.88 \pm 1.28$ & 7.8 & 9.5 & $8.65 \pm 0.63$ & 0.004 & - \\
\hline Transparency depth (m) & 1.1 & 3.5 & $1.75 \pm 0.6$ & 0.8 & 2.4 & $1.55 \pm 0.34$ & 0.015 & - \\
\hline Light intensity (lux) & 1343 & 50966 & $14180 \pm 17647$ & 776 & 2286 & $1636 \pm 531$ & 0.000 & - \\
\hline \multicolumn{9}{|l|}{ Water temperature $\left({ }^{\circ} \mathrm{C}\right)$} \\
\hline $10 \mathrm{~cm}$ layer & 16.27 & 22.67 & $19.11 \pm 1.95$ & 16.43 & 20.53 & $18.41 \pm 1.30$ & 0.060 & \multirow[t]{2}{*}{2.94} \\
\hline Bottom of photic layer & 16.0 & 21.6 & $18.96 \pm 1.28$ & 16.4 & 20.4 & $18.26 \pm 1.19$ & 0.067 & \\
\hline \multicolumn{9}{|l|}{$\mathrm{pH}$ of water } \\
\hline$(0-0.5 \mathrm{~m})$ layer & 7.1 & 7.87 & $7.30 \pm 0.33$ & 6.96 & 7.97 & $7.49 \pm 0.3$ & 0.049 & \multirow[t]{2}{*}{0.46} \\
\hline Bottom of photic layer & 6.12 & 8.25 & $7.18 \pm 0.61$ & 6.46 & 8.1 & $7.32 \pm 0.49$ & 0.189 & \\
\hline \multicolumn{9}{|l|}{ Dissolved Oxygen(mg/l) } \\
\hline$(0-0.5 \mathrm{~m})$ layer & 5.16 & 7.73 & $6.55 \pm 0.7$ & 5.55 & 7.1 & $6.32 \pm 0.39$ & 0.013 & \multirow[t]{2}{*}{0.39} \\
\hline Bottom of photic layer & 5.06 & 7.17 & $6.5 \pm 0.66$ & 5.61 & 7.2 & $6.30 \pm 0.43$ & 0.047 & \\
\hline \multicolumn{9}{|l|}{$\begin{array}{l}\text { Electrical Conductivity } \\
(\mu \mathrm{S} / \mathrm{cm})\end{array}$} \\
\hline$(0-0.5 \mathrm{~m})$ layer & 58.67 & 64.67 & $62.7 \pm 1.72$ & 59 & 64.33 & $61.51 \pm 1.42$ & 0.236 & \multirow[t]{2}{*}{0.1} \\
\hline Bottom of photic layer & 59.33 & 64.33 & $62.65 \pm 1.15$ & 59 & 63.67 & $61.38 \pm 1.23$ & 0.026 & \\
\hline \multicolumn{9}{|l|}{$\mathrm{NO}_{3}^{-}-\mathrm{N}(\mathrm{mg} / \mathrm{l})$} \\
\hline$(0-0.5 \mathrm{~m})$ layer & 0.06 & 1.85 & $1.35 \pm 0.56$ & 1.19 & 2.22 & $1.64 \pm 0.34$ & 0.019 & \multirow[t]{2}{*}{0.43} \\
\hline Bottom of photic layer & $*$ & 2.08 & $1.36 \pm 0.63$ & 0.91 & 2.06 & $1.54 \pm 0.34$ & 0.003 & \\
\hline \multicolumn{9}{|l|}{$\mathrm{NH}_{4}^{+}-\mathrm{N}(\mathrm{mg} / \mathrm{l})$} \\
\hline$(0-0.5 \mathrm{~m})$ layer & 0.1 & 0.64 & $0.3 \pm 0.19$ & 0.067 & 0.46 & $0.22 \pm 0.1$ & 0.007 & \multirow[t]{2}{*}{0.37} \\
\hline Bottom of photic layer & 0.07 & 0.89 & $0.29 \pm 0.22$ & 0.17 & 0.46 & $0.25 \pm 0.07$ & 5.48 & \\
\hline \multicolumn{9}{|l|}{$\mathrm{PO}^{3-}{ }_{4}-\mathrm{P}(\mathrm{mg} / \mathrm{l})$} \\
\hline$(0-0.5 m)$ layer & $*$ & 1.23 & $0.46 \pm 0.45$ & 0.19 & 0.92 & $0.55 \pm 0.26$ & 0.015 & \multirow[t]{2}{*}{0.36} \\
\hline Bottom of photic layer & $*$ & 1.15 & $0.51 \pm 0.41$ & 0.13 & 1.14 & $0.56 \pm 0.32$ & 0.152 & \\
\hline \multicolumn{9}{|l|}{ Chlorophyll $a(\mu \mathrm{g} / \mathrm{l})$} \\
\hline$(0-0.5 \mathrm{~m})$ layer & 11.21 & 52.33 & $23.71 \pm 11.21$ & 11.21 & 37.88 & $21.21 \pm 7.43$ & 0.102 & \multirow[t]{2}{*}{0.00} \\
\hline Bottom of photic layer & 3.73 & 22.43 & $8.81 \pm 5.26$ & 3.74 & 16.02 & $7.82 \pm 3.59$ & 0.045 & \\
\hline \multicolumn{9}{|l|}{$\begin{array}{l}\text { Abundance of } \\
\text { phytoplankton (cells or } \\
\text { individuals/l) }\end{array}$} \\
\hline$(0-0.5 m)$ layer & 0.162 & 11.47 & $2.1 \pm 2.7$ & 0.04 & 2.72 & $0.90 \pm 0.89$ & 0.000 & \multirow{2}{*}{1.61} \\
\hline Bottom of photic layer & 0.16 & 3.83 & $1.00 \pm 0.91$ & 0.04 & 0.75 & $0.31 \pm 0.23$ & 0.002 & \\
\hline Species richness & & & & & & & & \\
\hline$(0-0.5 \mathrm{~m})$ layer & 5 & 18 & $9.9 \pm 2.8$ & 4 & 13 & $9.1 \pm 2.6$ & 0.348 & - \\
\hline
\end{tabular}

(*): value below detection limit. 


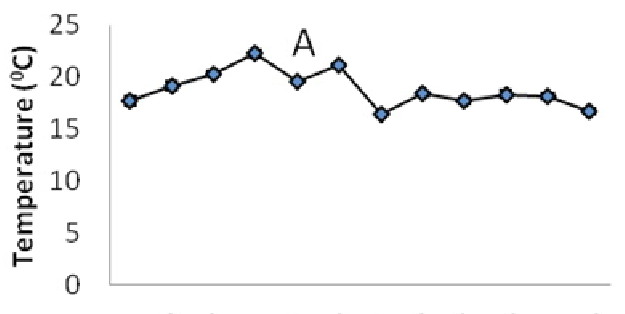

$\begin{array}{lllllllllllll}1 & 2 & 3 & 4 & 5 & 6 & 7 & 8 & 9 & 10 & 11 & 12\end{array}$ Months in 2014
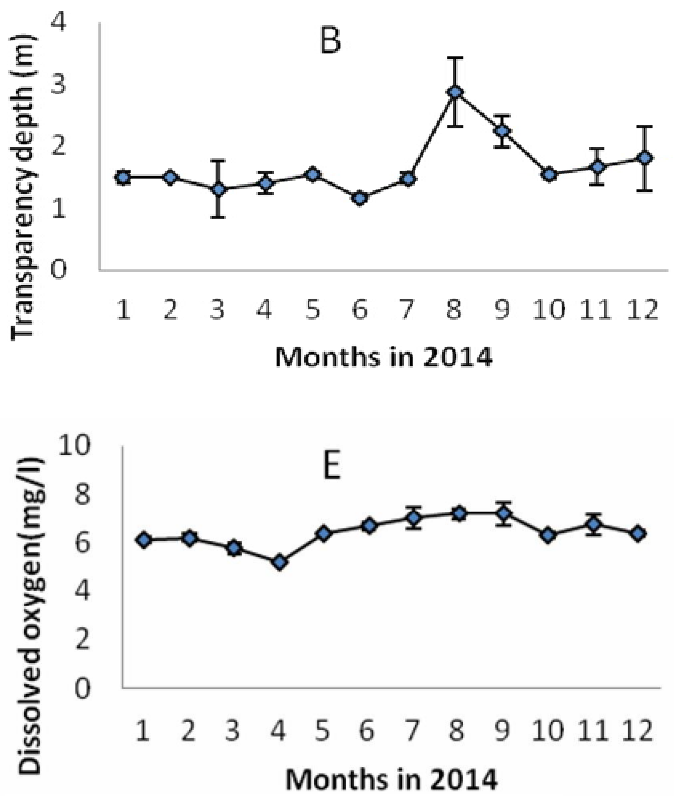

G
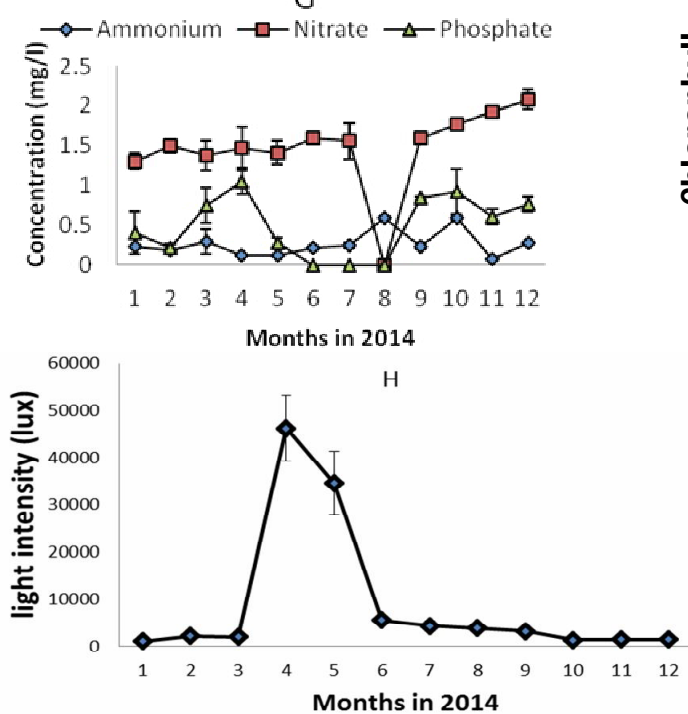
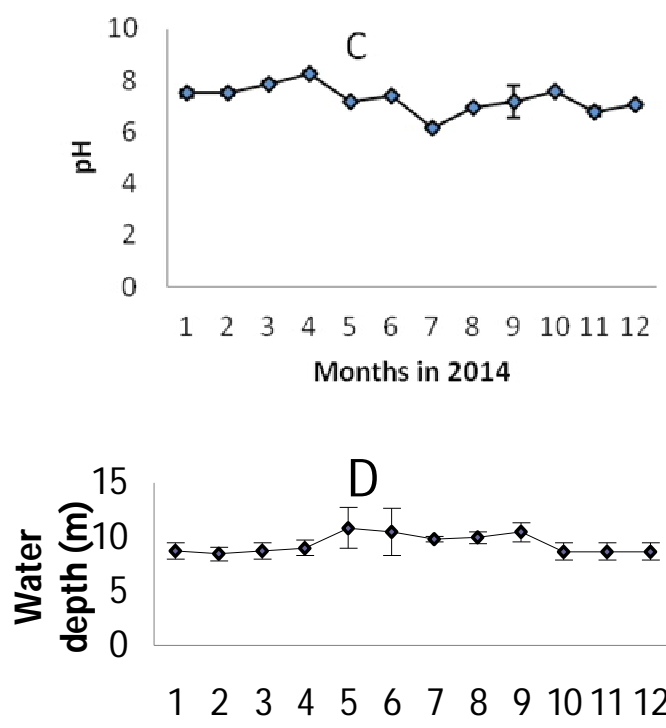

Monthsin 2014

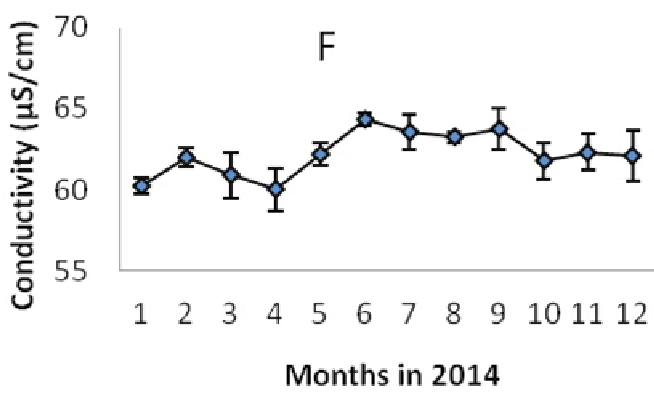

$\mathrm{H}$

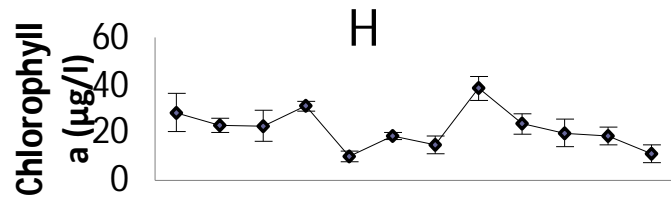

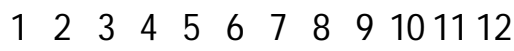

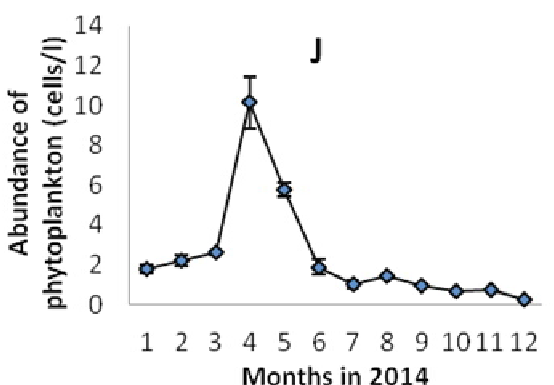

Figure 2. Average of water temperature (A), Transparency depth (B), pH (C), water depth (D), Dissolved oxygen (E), Conductivity (F), Concentrations of ammonium, nitrate and phosphate (G), Chlorophyll $a$ content $(\mathrm{H})$, Light intensity (I), and abundance of phytoplankton $(\mathrm{J})$ in Tuyen Lam reservoir at $0.5 \mathrm{~m}$. 


\section{Phytoplankton community}

Phytoplankton species composition of Tuyen Lam reservoir in 2014 consisted of 43 taxa, in 6 phyla, viz. Chlorophyta (58\%), Bacillariophyta (14\%), Cyanobacteria (14\%), Dinophyta (7\%), Chrysophyta (5\%) and Euglenophyta (2\%) (fig. 3A). Among the 43 algal taxa, Chlorophyta contributed the highest number of species (25), followed by Bacillariophyta (6) and Cyanobacteria (6). The other phyla, Dinophyta, Chrysophyta and Euglenophyta, contributed 3,2 and 1 species, respectively.
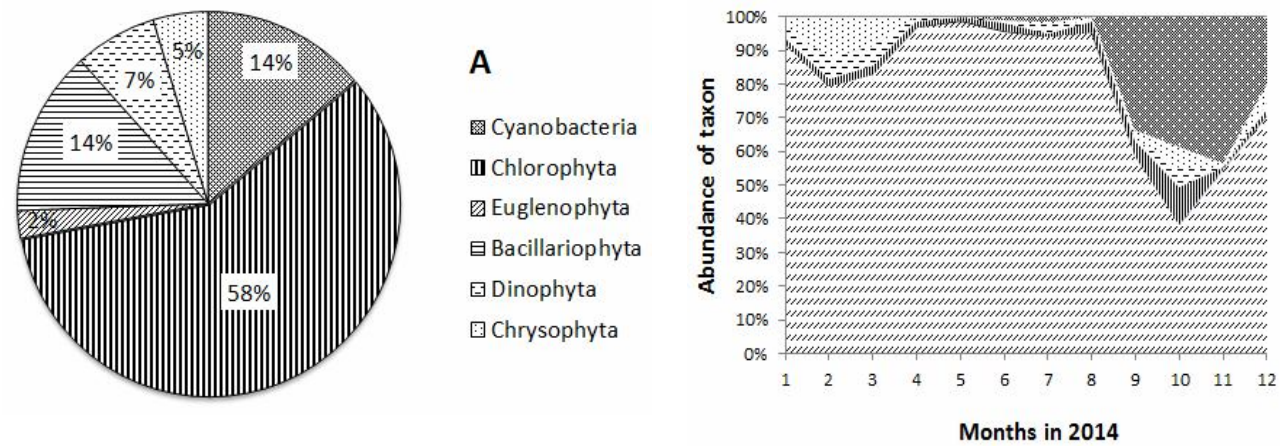

B

ehrysophyta

: Dinophyta

$\therefore$ Bacillariophyta

IIII Chlorophyta

m Cyanobacteria

Figure 3. (A) Taxonomical percentage composition and (B) abundant percentage of phytoplankton in Tuyen Lam reservoir during 2014

Table 2. Phytoplanktonic species in Tuyen Lam reservoir during 2014

\begin{tabular}{|c|c|c|c|c|c|c|c|c|c|c|c|c|c|c|c|}
\hline \multirow{2}{*}{$\mathrm{N}_{0}$} & \multirow{2}{*}{ Species } & \multirow{2}{*}{ Code } & \multirow{2}{*}{ Phylum } & \multicolumn{12}{|c|}{ During 2014} \\
\hline & & & & $\mathrm{J}$ & $\mathrm{F}$ & $\mathrm{Ma}$ & A & $\mathrm{M}$ & $\mathrm{J}$ & $\mathrm{Jl}$ & $\mathrm{A}$ & $\mathrm{S}$ & $\mathrm{O}$ & $\mathrm{N}$ & $\mathrm{D}$ \\
\hline 1 & Anabaena spiroides & Ansp & Cyanobacteria & + & & & & & & & & & & & + \\
\hline 2 & Merismopedia glauca & Megl & Cyanobacteria & & & + & & + & & & & & & & \\
\hline 3 & Microcystis sp. & Misp & Cyanobacteria & + & + & + & + & + & + & + & + & + & + & + & + \\
\hline 4 & $\begin{array}{l}\text { Microcystis } \\
\text { wesenbergii }\end{array}$ & Miwe & Cyanobacteria & + & + & + & + & + & + & + & + & + & + & + & + \\
\hline 5 & Oscillatoria sp. & Ossp & Cyanobacteria & + & + & & & + & & & & & & & \\
\hline 6 & $\begin{array}{l}\text { Woronichinia } \\
\text { naegeliana }\end{array}$ & Wona & Cyanobacteria & & & & & + & & & & & & & \\
\hline 7 & Actinastrumhantzchii & Acha & Chlorophyta & & & & & & & & & + & + & & + \\
\hline 8 & Botryoccocus braunii & Bobr & Chlorophyta & & + & + & + & + & & & + & & & + & + \\
\hline 9 & Chlamydomonas sp. & Chsp & Chlorophyta & & & & + & & + & + & & + & + & & \\
\hline 10 & Coelastrum cambrium & Coca & Chlorophyta & & + & & & & & + & + & & + & + & + \\
\hline 11 & Coelastrum recticulatum & Core & Chlorophyta & & & & & & + & & & & & & \\
\hline 12 & Cosmarium moniliforme & Como & Chlorophyta & & & + & & & & & & + & & & + \\
\hline 13 & $\begin{array}{l}\text { Cosmarium } \\
\text { pseudoconnatum }\end{array}$ & Cops & Chlorophyta & + & + & & + & & + & & + & + & + & + & + \\
\hline 14 & Crucigenia mucronada & Crmu & Chlorophyta & & & & & + & & & & & & & \\
\hline 15 & Desmidium baileyi & Deba & Chlorophyta & & & & & + & & & & + & & & \\
\hline 16 & $\begin{array}{l}\text { Dictyosphaerium } \\
\text { pulchellum }\end{array}$ & Dipu & Chlorophyta & & & & & & & & + & + & & + & + \\
\hline 17 & Elakatothrix sp. & Elsp & Chlorophyta & & & & & + & & + & & & & & \\
\hline
\end{tabular}




\begin{tabular}{|c|c|c|c|c|c|c|c|c|c|c|c|c|c|c|c|}
\hline 18 & Kirchneriella sp. & Kisp & Chlorophyta & + & & & & + & & & & & & & \\
\hline 19 & $\begin{array}{l}\text { Nephrocytium } \\
\text { agardhianum }\end{array}$ & Neag & Chlorophyta & & & & + & & & & & & & & + \\
\hline 20 & Oocystis sp. & Oosp & Chlorophyta & & + & + & + & + & + & + & & + & & & \\
\hline 21 & Pandorina charkowiensis & Pach & Chlorophyta & & + & & & + & & + & + & & + & & \\
\hline 22 & Pleurotaenium sp. & Plsp & Chlorophyta & & & & & + & & & & & & & \\
\hline 23 & Scendesumus sp. & Scsp & Chlorophyta & & & & & & & & & & & + & \\
\hline 24 & $\begin{array}{l}\text { Scendesumus } \\
\text { quadricauda }\end{array}$ & Scqu & Chlorophyta & & & & & + & & & & & & & \\
\hline 25 & Sphaerocystis sp. & Spsp & Chlorophyta & & & & & + & & & & & & & \\
\hline 26 & Staurastrum sp. & Stsp & Chlorophyta & & & + & & & & & & & & + & + \\
\hline 27 & Staurastrum arctiscon & Star & Chlorophyta & + & + & + & & + & + & & & & & & \\
\hline 28 & $\begin{array}{l}\text { Staurastrum } \\
\text { dorsidentiferum }\end{array}$ & Stdo & Chlorophyta & & & + & & & & & & & & & \\
\hline 29 & $\begin{array}{l}\text { Staurastrum } \\
\text { pentacerum }\end{array}$ & Stpe & Chlorophyta & & & + & & & & & & & & & \\
\hline 30 & Staurastrum cuspidatus & Stcu & Chlorophyta & & & + & & & & & & & & & \\
\hline 31 & Tetraedron gracile & Tegr & Chlorophyta & & & & & + & & & & & & & + \\
\hline 32 & Phacus sp. & Phsp. & Euglenophyta & & & & & + & & & & & & & \\
\hline 33 & Aulacoseira sp1. & Ausp1 & Bacillariophyta & + & + & + & + & + & & + & & & + & + & + \\
\hline 34 & Aulacoseira sp2. & Ausp2 & Bacillariophyta & & & + & + & & & & & & & & \\
\hline 35 & Cymbella sp. & Cysp & Bacillariophyta & & & & + & + & + & + & + & & & & \\
\hline 36 & Pinnularia sp. & Pisp & Bacillariophyta & & & & & + & & & & & & & \\
\hline 37 & Synedra sp. & Sysp & Bacillariophyta & & & & & + & & + & & + & & & \\
\hline 38 & Urosolenia sp. & Ursp & Bacillariophyta & & & & & + & & & & & & & \\
\hline 39 & Ceratium hirundinella & Cehi & Dinophyta & + & + & + & + & & + & + & + & + & & + & \\
\hline 40 & Peridinium cinctum & Peci & Dinophyta & & & & & & & & + & & & + & \\
\hline 41 & Peridium sp. & Pesp & Dinophyta & + & + & + & + & + & + & + & & & & & + \\
\hline 42 & Dinobryon sp. & Disp & Chrysophyta & & & & & & + & + & & & + & + & + \\
\hline 43 & Synura sp. & Sysp & Chrysophyta & & & & & & & & + & & & & \\
\hline
\end{tabular}

(+): present; J, F, Ma, A, M, J, Jl, Au, S, O, N, D=January, February, March, April, May, June, July, August, September, October, November, December.

Based on phytoplankton composition, Tuyen Lam reservoir was typical of lentic environments, with dominant of chlorophytes and diatoms. The was only one Phacus species in phylum Euglenophyta recorded. This algal group was known abundance in the waters with high organic matter. Dinophyta and Bacillariophyta had a minor contribution to the total phytoplankton abundance; Cyanobacteria and Chrysophyta contributed major portion of the total phytoplankton abundance (fig. 3B). The chrysophytes, however, only became more abundance at the end of the year (fig. 3B). The highest phytoplankton density was observed in the rainy season $\left(11.47 \times 10^{6}\right.$ cells/l), while the lowest were in the dry season $\left(0.041 \times 10^{6}\right.$ cells $\left./ \mathrm{l}\right)$ at both water layers (ANOVA, $\mathrm{p}=0.000$; $\mathrm{p}=0.002$, respectively). There was no different in phytoplankton abundance at depths (ANOVA; $\mathrm{p}=1.61$ ). In order to describe relationship between total phytoplankton abundance (TAP) and abiotic variable revealed that TAP (on log scaled) was depending on only 3 fitting independent abiotic variables (ammonium, nitrate and water temperature), a multiple linear regression model was apply as 
follows:

$$
\begin{gathered}
\log (\mathrm{TAP})=-3.9071-0.36882 * \log \left(\mathrm{NH}_{4}{ }^{+}\right)- \\
3.14209 * \log \left(\mathrm{NO}_{3}^{-}\right)+0.273314 * \text { water } \\
\text { temperature }
\end{gathered}
$$

During 2014, chlorophyll $a$ contents were $21.21 \pm 7.43 \mu \mathrm{g} / 1$ in the dry and $23.71 \pm 11.21 \mu \mathrm{g} / 1$ in the rainy seasons (fig. $2 \mathrm{H}$ ). Chlorophyll $a$ content was not significantly different between seasons at $0.5 \mathrm{~m}$ (ANOVA, $\mathrm{p}=0.102)$ but higher at surface than in the bottom of photic zone layers (ANOVA, $\mathrm{p}=0.045$ ). Results of a multiple linear model for the relationship between chlorophyll $a$ (Chla) and abiotic parameters revealed only one fitting independent factor, $\mathrm{pH}$, and the equation of the fitted model was as folows:

$$
\log (\text { chla })=0.84033+0.29442 * p H
$$

The result of the CCA for relationships between species composition of phytoplankton and environmental variables are summarized in table 3 and fig. 4. The axis 1 of CCA had an eigenvalue of 0.347 and explained $28.2 \%$ of the total variance in phytoplankton species. The second axis had an eigenvalue of 0.173 and explained $42.3 \%$ of the total variance. The eigenvalues of axes 1 and 2 explained $42.3 \%$ of the variance of the species data. Environmental variables explained $46 \%$ of the explanation was summarized by the first two axes.

Table 3. Statistical summary for phytoplankton species and abiotic variables on the first two CCA axes for the Tuyen Lam reservoir

\begin{tabular}{lc|c}
\hline & Axis 1 & Axis 2 \\
\hline 1. Eigenvalues & 0.347 & 0.173 \\
2. Species-environment correlations & 0.994 & 0.999 \\
3. Cumulative percentage variance of species data & 28.2 & 42.3 \\
4. Cumulative percentage variance of species-environment relation & 30.7 & 46.0 \\
\hline
\end{tabular}
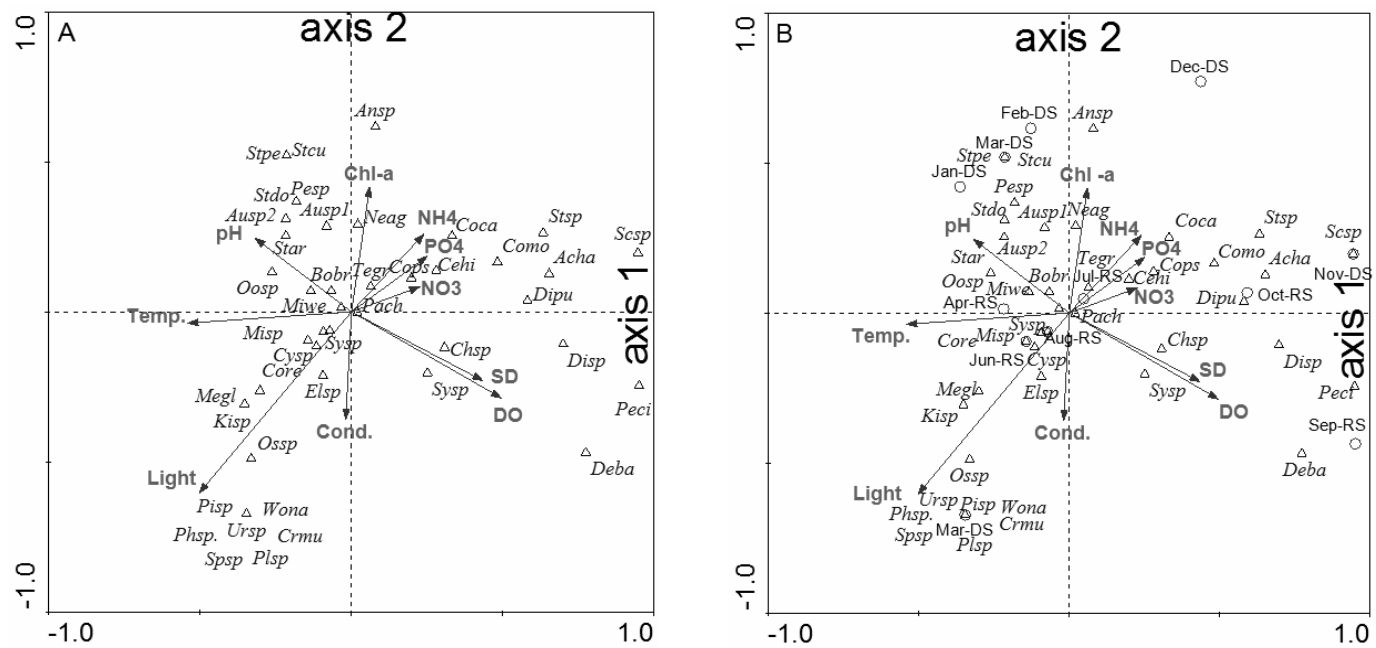

Figure 4. The ordination diagrams of CCA. CCA biplot illustrating the presence of the species (abbreviated names as in table 2) and environmental variables in Tuyen Lam reservoir in 2014. Species are expressed as open triangles. Months are expressed as open circles. Environmental factor are shown as arrows with their origin at average values, extending towards higher values. $\mathrm{pH}=$ concentration of proton, Temp=water temperature; $\mathrm{SD}=$ Secchi Depth; Light=Light intensity; $\mathrm{NH} 4=$ ammonia concentration; $\mathrm{DO}=$ Dissolved Oxygen; $\mathrm{NO} 3=$ nitrate concentration, $\mathrm{PO} 4=$ phosphate concentration; Chl-a=chlorophyll $a$ content; DS=Dry season and RS=Rainy season. Jan, Feb, Mar, Apr, May, Jun, Jul, Aug, Sep, Oct, Nov, Dec=January, February, March, April, May, June, July, August, September, October, November, December. 
There was no statistically significant differences in abundance of phytoplankton between seasons (ANOVA; $\mathrm{p}=1.198$ (table 1). Chlorophyta was represented in the studied reservoir by a large number of species, but in low cell numbers (fig. 3A, 3B). Dinophyte genera, such as Peridinium and Ceratium represented relatively high abundance in both seasons. These genera were usually abundance in nutrient rich habitats or mesotrophic lakes [33]. Ceratium is known as a genus growth rapidly at low nutrient concentrations [4]. In Tuyen Lam, there were two Cyanobacteria species, Microcystis wesenbergii and Microsystis sp., dominant throughout the year. Cyanobacteria are frequently found in eutrophic waters [6]. Chrysophyta were found from May to December (table 2) and became more abundance in September-December (fig. 3B). There was no differences in species richness of phytoplankton between two seasons (ANOVA, $\mathrm{p}=0.348)($ table 1$)$.

In the ordination diagrams of CCA (fig. 4), several species groups were formed with associated environmental parameters and sampling months. A groups including Woronichinia naegeliana, Crucigenia mucronada, Pleurotaenium sp., Sphaerocystis sp., Phacus sp., Pinnularia sp., and Urosolenia sp. was placed together near light intensity vector. These species were found only in March (fig. 4B), at the end of the dry season, when light intensity was high. These species are known as photophilic species [10]. Chlamydomonas sp. and Synedra sp. were found in the positive part of the second axis and were related to high dissolved oxygen and low Secchi depth (fig. 4). These species may tolerance to higher mixed and turbid water. Other groups as Coelastrum cambrium, Cosmarium pseudoconnatum, Pandorina charkowiensis and Ceratium hirundinella were found in the positive part of the second axis and related to low nutrient concentrations in July. Three Cyanobacteria species, Microcystis sp., Microcystis wesenbergii, and Oscillatoria sp., were grouped together near water temperature and $\mathrm{pH}$ vectors. These species were related to high water temperature and low $\mathrm{pH}$ values in the beginning of the rainy season (April). The CCA showed no clear seasonal pattern but rather phytoplankton groups in their favorable environmental conditions. The sampling units related to the rainy and the dry seasons were placed in both axes 1 and 2 (fig 4B). The first two axes of CCA explained $70.5 \%$ (28.2\% for axis 1 and $42.3 \%$ for axis 2) of total variance in phytoplankton species. So, there was $29.5 \%$ of unexplained variation at Tuyen Lam reservoir, but the unexplained variation was probably to other factors.

\section{CONCLUSION}

In summary, this study presented monthly and seasonally variation in water temperature, $\mathrm{pH}$, dissolved oxygen, light intensity, transparency, dissolved nutrient concentration, chlorophyll a content, and phytoplankton composition and abundance during 2014 in Tuyen Lam reservoir. Relationship between phytoplankton and abiotic parameters were analyzed by various statistical attempts. The controlling roles of some environmental parameters was presented by canonical correspondence analysis (as relationship of different algal groups to their particulate environmental conditions) and the multiple linear regression modeling (as total abundance of phytoplankton to dissolved nitrogenous and temperature). Dynamics of phytoplankton abundance in Tuyen Lam reservoir was controlled by two main phyla, Cyanobacteria and Chrysophyta. There was difference in the species composition and abundance of phytoplankton in during the study period. However, no different in species richness of phytoplankton was found between the two seasons.

Acknowledgments: We are thankful to Viet Nam Academy of Science and Technology for funding the Project VAST.HTQT.NGA.04/14 and Da Lat University for financial support. Dr. Nguyen Ngoc Lam and Phan Tan Luom are acknowledged for their help during the field trips.

\section{REFERENCES}

1. Adon M. P., Ouattara A., Gourene G., 2012. Phytoplankton composition of a shallow 
African tropical reservoir. Journal of Microbiology, Biotechnology, 5: 1189-1204.

2. APHA, 1995. Standard methods for the examination of water and wastewater (13th ed.). Washington, DC: American Public Health Association.

3. Bhanu P. M., Jyothi K. and Narasimha R. G. M., 2014. Seasonal variations of phytoplankton community structure in relation to Physico-chemical factors in Lake Kolleru, Andhra Pradesh, India. J. Algal Biomass Utln., 5(3): 1-7.

4. Bouvy M., Ngansoumana B., Samba K., Seyni S., Pagano M., Arfi R., 2006. Phytoplankton community structure and species assemblage succession in a shallow tropical lake (Lake Guiers, Senegal). Aquat Microb Ecol., 45: 147-161.

5. Cole G. A., 1994. Textbook of Limnology. 4th ed. Prospect Heights: Waveland Press Inc.

6. Havens K. E., 2008. Cyanobacteria blooms: effects on aquatic ecosystems. Advances in Experimental Medicine and Biology, 619: 733-747.

7. Hotzel G., and Groome R., 1999. A phytoplankton methods manual for Australian Freshwaters LWRRDC Occasional paper 22/99. La Trobe University Albury.

8. Ise G. S, Ariadnen N. M., and Enio W. D., 2012. Phytoplankton community of Reis lake in the Brazilian Amazon. Annals of the Brazilian Academy of Sciences, 85(2): 649663.

9. John D. W., Robert G. S., 2003. Freshwater algae of North America: Ecology and Classification. Academic Press.

10. Kemal C., Tugba O., 2007. The relationships between certain physical and chemical variables and the seasonal dynamics of phytoplankton assemblages of two inlets of a shallow hypertrophic lake with different nutrient inputs. Environ Monit Assess, 124: 321-330.

11. Komarek J., Anagnostidis K., 2000.
Cyanoprokaryota: Chroococcales. Spektrum Akademischer Verlag.

12. Komarek J., Anagnostidis K., 2005. Cyanoprokaryota: Oscillatoriales. Spektrum Academischer Verlag.

13. Ling S, Xiang C., Xiang C. J., Yuan Z., Yan L. Z., He L., Qui X. Z., Yuan Y. Z., 2009. Seasonal Dynamics of Phytoplankton in Relation to Key Aquatic. Habitat Factors in a Polluted Urban Small Water Body in Tianjin, China. Bull Environ Contam Toxicol., 82: 543-548.

14. López N. L, Carlos A. R., Rondon R., Zapata A., Jimenez J., Villamil W., Avenas G., Rincon C., Sanchez T., 2012. Factors controlling phytoplankton in tropical high mountain drinking-water reservoirs. Limnetica, 31(2): 305-322.

15. Lewis D. M., 1978. Analysis of succession in a tropical phytoplankton community and new measure of succession rate. Am. Nat., 112: 401-414. Li

16. Meesukko C., Gajaseni N., Peerapornpisal Y., Voinov A., 2007. Relationships between seasonal variation and phytoplankton dynamics in KaengKrachan reservoir, Phetchaburi Province, Thailand. The Natural History Journal of Chulalongkorn University, 7(2): 131-143.

17. Monika W., Hunter D. A., 2008. Temporal organization of phytoplankton communities linked to physical forcing. Oecologia, 156: 179-192.

18. Ma Rośelia M. Lopes, Carla F., Carlos E. M., 2009.Phytoplankton diversity and strategies in regard to physical disturbances in a shallow, oligotrophic, tropical reservoir in Southeast Brazil. Limnetica, 28(1): 159174.

19. Nabout J. C., Nogueria I. S., Oliveira L. G., 2006. Phytoplankton community of floodplain lakes of the Araguaia River, Brazil, in the rainy and dry seasons. Journal of Plankton Research, 28(2): 181-193.

20. Nguyen T. T. L, Cronberg G., Lasen J., 2007. Planktic cyanobacteria from freshwater localities in ThuaThien Hue 
province, Vietnam. Taxonomy and distribution. Nova Hedwigia, 85: 1-34.

21. Nguyen T. T., 1997. The freshwater algae of Nam Cat Tien National park. Bulletin of natural science, No 1. College of Natural Science, Vietnam, pp 57-72.

22. Pallavi S., Ajay S., 2013. A Seasonal variations of plankton population of Maheshara Lake in Gorakhpur, India.World Journal of Zoology, 8(1): 09-16.

23. Paulette A. M., Allassane O., Germain G., 2011. Seasonal variation in the diversity and abundance of phytoplankton in a small African tropical reservoir. African Journal of Microbiology Research, 5(18): 26162626.

24. Panigrahi S., Patra A. K., 2013. Studies on seasonal variations in phytoplankton on diversity of river Mahanadi, Cuttack city, Odisha, India. Indian J. Sci. Res., 4(2): 211217.

25. Reynolds C. S., Huszar V., Kruk C., Naselli L., Melo S., 2002. Towards a functional classification of the freshwater phytoplankton, J. Plankton Res., 24: 418428.

26. Scheffer M., E. H. van Nes, 2007. Shallow lakes theory revisited: various alternative regimes driven by climate, nutrients, depth and lake size. Hydrobiologia, 584: 455-466.

27. Shirota A., 1966. The plankton of South
Vietnam - Freshwater and Marine plankton. OTCA, Japan, 462p.

28. Temponeras M., Kristiansen, J., Moustaka, M., 2000. Seasonal variation in phytoplankton composition and physicalchemical features of the shallow Lake Doïrani, Macedonia, Greece. Hydrobiologia, 424: 109-122.

29. Tran T. T., 2014. Assessment eutrophic state of some reservoir in Dalat city with TSI and AQ index. Jounal of Tay Nguyen University, 13: 36-43.

30. Valério E., Faria N., Paulino S., Pereira P., 2008. Seasonal variation of phytoplankton and cyanobacteria composition and associated microcystins in six Portuguese freshwater reservoirs. Ann. Limnol. - Int. J. Lim, 44-(3): 189-196.

31. Vollenweider R. A., 1969. A manual on methods for measuring primary production in aquatic environments, IBP Handbook No, 12 International Biological Programme, Blackwell Scientific Publications, Oxford (chapter 3).

32. Xuechu C., Xiaodong W., 2009. Seasonal variation of mixing depth and its influence on phytoplankton dynamics in the Zeya reservoir, China. Limnology, 10: 159-165.

33. Wetzel R. G., 2001. Limnology, Third Edition: Lake and River Ecosystems (pp 196-220). Publisher: Academic Press. 


\title{
BIẾN ĐộNG CẤU TRÚC THỰC VẬT PHÙ DU TRONG HỒ TUYỀN LÂM, ĐÄ LẠT, VIẸT NAM
}

\author{
Trần Thị Tình ${ }^{1}$, Đoàn Như Hải ${ }^{2}$, Lê Bá Dũng ${ }^{1}$ \\ ${ }^{1}$ Trường Đại học Đà Lạt \\ ${ }^{2}$ Viện Hải Dương học Nha Trang, Viện Hàn lâm KH \& CN Việt Nam
}

\section{TÓM TẮT}

Biến động cấu trúc thực vật phù du trong hồ Tuyền Lâm thuộc thành phố Đà Lạt, Việt Nam đã được phân tích quamùa mưa và mùa khô, từ tháng 1 đến tháng 12 năm 2014. Mẫu được thu hàng tháng tại 3 vị trí của hồ. Mục đích của nghiên cứu nhằm phân tích cấu trúc quần xã thực vật phù du theo mùa; xác định ảnh hưởng của yếu tố môi trường (nhiệt độ, độ dẫn điện, $\mathrm{pH}$, oxy hòa tan, cường độ ánh sáng, độ truyền quang, nồng độ amoni, nitrat và phosphate) đến thành phần loài và mật độ thực vật phù du. Kết quả đã xác định được 43 taxon, trong đó ngành tảo lục có số lượng taxon nhiều nhất (chiếm tới $58 \%$ ), kế tiếp là ngành tảo silic (14\%), vi khuẩn lam (14\%), tảo giáp (7\%), tảo vàng ánh $(5 \%)$ và tảo mắt $(2 \%)$. Nghiên cứu cũng đã chỉ ra được sự khác nhau đáng kể về mật độ thực vật phu du giữa mùa khô và mùa mưa. Tuy nhiên, không có sự khác nhau đáng kể về thành phần loài giữa hai mùa. Phân tích hồi quy đa biến giữa hàm lượng diệp lục tố a, mật độ thực vật phù du với các yếu tố môi trường cho thấy nồng độ amoni, nitrat và nhiệt độ nước có tương quan chặt với mật độ thực vật phù du, trong khi đó hầu như không có biến môi trường nào có quan hệ với hàm lượng diệp lục tố $\mathrm{a}$. Các phân tích $\mathrm{CCA}$ giữa thực vật phù du và biến môi trường đã thể hiện các nhóm loài cùng với những đặc trưng điều kiện môi trường của chúng.

Tù khóa: Biến động theo mùa, hồ chứa, thực vật phù du, yếu tố môi trường.

Ngày nhận bài: 3-6-2015 